ankara TurizM FAKüLtesi DERgisi

Dergi Ana Sayfası: https://dergipark.org.tr/tr/pub/ahbvtfd

ISSN: $2687-1912$

DOI: $10.34189 /$ tfd.24.02.002

\title{
Covid-19 Pandemi Sürecinde Aile İçi Rekreasyonel Etkinliklerde Somut Olmayan Kültürel Miras Ulusal Unsurlarının Üstlenebileceği Rol
}

(The Role That Intangible Cultural Heritage National Elements in In-Family Recreation Activities Might Take During Covid-19 Pandemic)

\author{
Damla ERDEM $^{\mathrm{a} *} \quad$ Bilgehan GÜLCAN ${ }^{\mathrm{b}}$ \\ ${ }^{a}$ Kırklareli Üniversitesi, Turizm Fakültesi, Rekreasyon Yönetimi Bölümü, Kırklareli-Türkiye (damlaerdem@klu.edu.tr) \\ https://orcid.org/0000-0001-9792-7109 \\ b Ankara Hacı Bayram Veli Üniversitesi, Turizm Fakültesi, Rekreasyon Yönetimi Bölümü, Ankara-Türkiye (bilgehan.gulcan@hbv.edu.tr) \\ https://orcid.org/0000-0002-9884-4695
}

MAKALE GEÇMİ̧̧i

Gönderim Tarihi:

27.08.2021

\section{Kabul Tarihi: \\ 17.09.2021}

\section{Anahtar Kelimeler:}

Somut Olmayan Kültürel Miras

(SOKÜM)

COVID-19

Aile

Rekreasyon

Kültürel Sürdürülebilirlik

\section{Keywords:}

Intangible Cultural Heritage (ICH) COVID-19

Family

Recreation

Cultural Sustainability

\section{Makalenin Türü: Derleme}

*Sorumlu Yazar: Damla ERDEM

E posta: damlaerdem@klu.edu.tr
ÖZ

İçinde yaşadığımız COVID-19 pandemi döneminde, tüm dünyadaki bireyler evlerinde daha fazla zaman geçirmek zorunda kalmaktadır. Bu durumun aile içindeki bireyleri hem tek başlarına ve hem de beraberce keyifli ve verimli zaman geçirme arayışına yönelttiği, bunun yapılmaması durumunda da yoğun stres ile yüz yüze kalındığı yaygın biçimde gözlenmektedir. Bu arayıșta ülkelerin Somut Olmayan Kültürel Miras (SOKÜM) ulusal envanterleri içindeki bazı unsurların, söz konusu arayışa cevap olabilecek potansiyel sunabildiği ve pandemi sürecinin SOKÜM unsurlarının sürdürülebilirliğine aynı zamanda bu yönüyle de katkı firsatı yarattı̆̆ı gözlenmektedir. Bu bağlamda çalışmanın amacı pandemi sürecinde SOKÜM ulusal unsurlarının aile içi rekreatif etkinliklerde ne derece rol alabileceği sorusuna cevap verebilmek ve pandemi sürecinin SOKÜM unsurlarının sürdürülebilirliğine katkı yapabileceği çıkarımına yönelik kanıtlar bulabilmektir. Çalışma belirlenen anahtar kelimelerle seçilmiş veri tabanlarında pandemi sürecinde yayınlanan makalelerin sistematik derlemesi ile gerçekleştirilmiştir. Buna ek olarak konuyla ilgili çeșitli gazete haberleri de analiz edilmiştir. COVID-19 Pandemi sürecinin başlangıcı düşünüldüğünde, araştırmanın en büyük sınırının konu ile ilgili sınırlı literatür olduğu açıktır. Bu şartlarda elde edilen sonuçlara göre, COVID-19 pandemi sürecinde aile içi rekreasyonel etkinliklerde SOKÜM ulusal unsurlarının belli bir rol üstlendiği, bazı ulusal SOKÜM unsurlarının toplumda yeniden gündeme geldiği anlaşılmıştır.

\section{ABSTRACT}

During the COVID-19 period we live in, all individuals are forced to spend more time in their homes. It has been commonly encountered that this circumstance led individuals within families to pursue ways to spend more enjoyable and effective time together or alone, and in case of not being able to achieve this, individuals have been faced with intense stress. In this pursuit, it was seen that some elements found in the countries' national inventory of Intangible Cultural Heritage (ICH) might offer required potential that could be the answer to the pursuit in question and pandemic process can make a contribution to the sustainability of ICH elements within this dimension. In this context, the study aims to address the question of to what extent $\mathrm{ICH}$ national elements can play a role in domestic recreational activities during the pandemic process and uncover evidence for the statement that the pandemic process can contribute to the sustainability of ICH elements. The study was carried out by systematically compiling publications published throughout the pandemic in selected databases using the specified keywords. On top of that, several newspaper articles and news were analyzed. Considering the outset of the COVID-19 pandemic, the utmost constraint of the study is clearly the limited literature sources on the subject. Looking at obtained results under these circumstances, it is understood that national elements of $\mathrm{ICH}$ had a role in domestic recreational activities during the COVID-19 pandemic and that some national elements of ICH have become a current issue in society.

Makalenin Künyesi: Erdem, D. ve Gülcan, B. (2021). Covid-19 Pandemi Sürecinde Aile İçi Rekreasyonel Etkinliklerde Somut Olmayan Kültürel Miras Ulusal Unsurlarının Üstlenebileceği Rol. AHBVÜ Turizm Fakültesi Dergisi, 24 (2), 192-215. 


\section{GíRiş}

Dünya Sağlık Örgütü (DSÖ) tarafından 11 Mart 2020’ de yeni tip Koronavirüsün (COVID19) küresel bir salgın olarak duyurulması ile başlayıp, günümüz çağının şu ana kadarki belki de en güncel konularından biri haline gelen COVID-19 pandemisinin tüm dünyayı derinden etkilediği yadsınamaz bir gerçektir (Landry vd., 2020: 2). DSÖ bu durumu yakından takip etmekte ve koronavirüsün yayılımını yavaşlatmak ve sınırlamak adına öneri niteliğinde tedbir kararları hazırlamaktadır (WHO, 2020). Dünyanın dört bir yanında ki ülkelerin, bu tavsiye niteliğindeki kararlardan yasal yaptırımlara kadar değişen düzenleyici eylemleri yürürlüğe koyduğu görülmektedir (Shamshiripour vd., 2020: 1).

Böylelikle kısa bir zaman diliminde tüm dünyaya yayılan koronavirüs, insanlık için ciddi anlamda bir tehdit olarak kabul edilmekte ve çeşitli tedbirler alınarak salgına karşı mücadele verilmekte, tüm ülkelerde olduğu gibi Türkiye'de de bu süreçte sıkı tedbirler alınmaktadır. Türkiye Cumhuriyeti Sağlık Bakanlığı tarafından koronavirüs tedbirleri kapsamında gerçekleştirilen kısıtlama uygulamaları ile birlikte seyahat yasakları başta olmak üzere kongre, konferans, fuar ve festivaller, ulusal ve uluslararası spor müsabakaları gibi çok sayıda organizasyonun iptal edildiği veya ertelendiği görülmektedir (Saglik, 2020). Bu kapsamda Millî Eğitim Bakanlığı tarafından eğitime geçici olarak ara verilmesi ve öğrencilerin uzaktan eğitim sistemi ile öğrenimlerine evden devam etmeleri gerektiği kararı da alınmış ve uygulamaya koyulmuştur (MEB, 2020).

Gerek bireyler arası temasın sınırlanması, bu kapsamda okullarda eğitime ara verilmesi, birçok ticari ve görev etkinliklerinin evlerden yürütülmesi ve boş zamanların değerlendirildiği birçok alanda faaliyetlerinin durdurulması sonucunda, bireylerin evde kalma süreleri dramatik biçimde artmıştır (Gümüşgül ve Aydoğan, 2020: 108). Tüm bu gelişmeler bireyleri, boş vakit geçirme konusunda gerek bağımsız gerekse aile içinde toplu biçimde eğlenceli ve verimli yollar arayışına itmiştir. Evde geçirilen zamanın artmasına bağlı bu arayışın bir sonucu olarak, SOKÜM ulusal unsurlarının bireylere ve farklı bireylerden oluşan ailelere verimli ve eğlenceli zaman geçirme firsatı sunarak cazip bir ortam yarattığı düşünülmektedir. Böylece araştırma hem bireysel hem de anne-baba ve çocukların pandemi sürecinde beraberce etkinlikler yapabileceği SOKÜM ulusal unsurlarının yarattığı verimli ve eğlenceli vakit geçirme firsatını analiz etmeyi amaçlamaktadır. Sürecin zorlukları yanında sunduğu böyle bir firsatın, sadece bireylerin verimli ve eğlenceli vakit geçirmeleri için değil aynı zamanda birçoğu unutulmuş 
ve/veya ihmal edilmiş SOKÜM ulusal unsurlarının yeniden üretilerek, bu unsurların sürdürülebilirliğine de katkı yapabileceği düşünülmektedir. Bu sayede aile içinde beraberce boş zaman geçirme zorluğu eğlenceli bir firsata dönüşebilecek, özellikle mobil cihazlara bağl1 olarak sosyal medyada vakit geçirme eğilimine daha fazla girmiş olan her yaştaki bireylerin SOKÜM ulusal unsurları ile daha yakından tanışma firsatı elde edilebilecektir.

\section{LITERATÜR TARAMASI}

"Kültürel mirasın bireyle ilişkisinin somut hali rekreasyon ile ortaya çıkmaktadır” (Kurtar, 2012: 35). Bireyler boş zamanlarında rahatlama, eğlenme ve dinlenme ihtiyacı duymaktadırlar. $\mathrm{Bu}$ nedenle bu ihtiyaçların karşılanması amacı ile bireyler boş zamanlarında çeşitli faaliyetlere katılım göstermektedirler. $\mathrm{Bu}$ kapsamda katılım tercihine göre de rekreasyon etkinliklerinin iki grupta sınıflandırılarak ele alındığı görülmektedir. Dalkılıç ve Mil'e göre (2017: 43) bu etkinlikler, evde ve ev dışında yapılan rekreatif etkinlikler olmak üzere iki başlıkta toplanmaktadır. Evde yapılan rekreatif etkinlikler, müzik ve radyo dinlemek, televizyon izlemek, kitap okumak, oyun oynamak, fiziksel egzersizler, hobiler, el işi etkinlikleri ve sohbet etmek gibi etkinlikler olarak gruplandırılırken; ev dışında yapılan etkinlikler ise, sportif etkinlikler, macera ve eğlence aktiviteleri, hobiler, çeşitli alan ve müze ziyaretleri, yemek yeme, temalı parklara gitme biçiminde sınıflandırılmaktadır. Bireyler, etkinliklere ya rol alarak (aktif) ya da izleyici (pasif) olarak dâhil olabilmektedirler. Aktif bir biçimde ev ortamında hem tek başlarına hem de beraberce yerel yemekleri deneme, puzzle yapma, geleneksel zekâ ve strateji oyunları oynama, el sanatları ile uğraşma, saklambaç, körebe, birdirbir ve benzeri çocuk oyunları oynama gibi anne-baba ve çocukları zihinsel ve fiziksel açıdan dinamik tutabilecek etkinlikler gerçekleştirilebilir. Pasif olarak ise izleyici olarak katıldıkları boş zamanı değerlendirme etkinlikleri, müzik dinleme, geleneksel seyirlik sanat ve oyunlarını (kukla, karagöz) izleme, masal ve hikâye dinleme gibi örnekler ile zenginleştirilebilir (Hacıoğlu vd., 2017: 35).

Pandemi döneminde kapalı alan rekreasyonun içerdiği ev içi rekreatif etkinliklere aile ile katılım sağlanması eşler, anne-baba ve çocuklar arasında sağlam ilişkiler kurulabilmesi için etkin bir yol olarak ifade edilmektedir. Aynı zamanda bireylerin çocukluk dönemlerinde, aileleri ile katılmış oldukları etkinliklerin de zihinlerinde geniş bir yer tuttuğu savunulmaktadır (Tekin vd., 2017: 17). Bir başka çalışmada ise anne-babaya ilişkin özellikler ve kişilik yapılarının çocukların oyun oynama tarzları ile ilişkili olduğu ifade edilmekte ve 
evdeki genel bir oyun ortamının, çocukların oyun anlayışını şekillendirici etkisinin olabileceği de öne sürülmektedir (Kılbaş, 2010: 225). Bu bağlamda, yeni nesillerin zihinlerinde geçmişin izlerini taşıyan SOKÜM'e olan merakın, aile içi rekreatif etkinlikler ile desteklenerek canlandırılması, kültür mirasına olan ilginin artırılması açısından kolaylaştırıcı bir rol üstlenmektedir (Gürel ve Çetin, 2019: 91). Çünkü somut olmayan kültürel mirasın aktarım yollarının gerek okulda gerekse evde aile içi eğitim ile veya kendiliğinden öğrenme yoluyla, akraba ve komşularında katkıları ile oluştuğunu ifade etmek mümkündür (Gürçayır Teke, 2013: 32).

Pandemi sürecinde evde daha çok zaman geçirmek durumunda kalan ailelerin, olumlu ve olumsuz durumları deneyimledikleri belirtilmektedir. Olumlu etkisi olarak, aile içi bağlılık ve etkileşimin arttığı ifadesine yer verilmektedir. Bu bağlamda Başaran ve Aksoy (2020: 674), eşler, anne-baba ve çocuklar arasında yapılan etkinliklerin ve bu sayede aralarındaki etkileşim sürelerinin arttığını öne sürmektedirler. Yazarlar, aile üyeleri arasında oyun oynama ve çeşitli aktivitelerin gerçekleştirilmesinin yanı sıra, bu sürecin rutin ev işlerinin de beraberce yapılmasına da firsat tanıdığına işaret etmektedirler. Szabo vd. (2020: 570) değindiği üzere, evde aile üyeleri ile geçirilen sürenin artması paylaşma ve yardımlaşma duygusunu pekiştirmekte, bu bağlamda Göl-Güven, vd. (2020: 6) değindiği gibi bireylerin evde kaldıkları süre zarfinda en çok tercih ettikleri etkinliğin "ebeveyn/bir yetişkin ile oyun oynamak" ve bunun sonucu olarak “aile üyeleri ile sosyalleşme”nin ortaya çıktığı anlaşılmaktadır. Tüm bu çalışmaların ortak paydası olarak, pandemi süreci, ev ortamında aile üyeleri ile birlikte geçirilen zamanı verimli bir biçimde değerlendirmek ve bunu faydaya dönüştürmek için çeşitli fırsatlar sunmaktadır. Bu noktada boş zamanın ailecek verimli ve eğlenceli değerlendirilmesi adına yapılacak ortak etkinlikler için SOKÜM ulusal unsurlarının önemli derecede kaynaklık edebileceği akla gelmektedir.

Uzun süre evde kalmanın söz edilen bu faydalarınn yanında önemli olumsuz etkilerinin de olduğunu dile getirmek mümkündür. Mesai kavramını anlamsız hale getirecek şekilde birçok işin eve taşınması ve özellikle eğitimin ev ortamında online olarak gerçekleşmesi hem internet kullanımını hem de ekran başında geçirilen süreyi artırarak kişilerin psikolojik durumlarını sarsmakta, bu durum beraberinde kişilerin hareket alanını kısıtlayarak fiziksel sorunlara da yol açabilmektedir. Türkiye İstatistik Kurumu (TÜİK) tarafından gerçekleştirilen "Hanehalkı Bilişim Teknolojileri Kullanım Araştırması" COVID-19 pandemi döneminde, internet 
kullanım oranının \%79,0 ‘a ulaştığını açıklamıştır. Bu oranın bir önceki yıl \% 73,3 olduğu görülmektedir. Bununla birlikte evden internete erişim imkânının ise, bir önceki yıl \%88,3 iken 2020 yılında bu oranın \%90,7'ye ulaştığı saptanmıştır (TÜİK, 2020). Bu durumun bir yansıması olarak, pandeminin sosyal medya bağımlılı̆̆ını tetiklediğini ifade etmek yerinde olabilir. Dikmen, (2021: 28) bu süreçte sosyal mesafenin korunması gerekliliğinden dolayı, bireylerin artan sosyalleşme ve iletişim ihtiyacının gidermeye çalışılması amacı ile sosyal medya bağımlılı̆̆ının arttığı görüşünü ileri sürmektedir.

Modern teknoloji kullanımıyla beraber yüz yüze iletişimin azaldığı daha çok telefon, tablet, bilgisayar gibi elektronik cihazlara olan yönelimin mobil uygulamalarda geçirdiğimiz süreyi artırabildiği gibi, bu durum bireylerin kültürel miraslarına olan hassasiyetlerinin zayıflamasına da neden olabilmektedir (Taştan, 2020:4; Gürel ve Çetin, 2019: 91). Böylelikle, artan sosyalleşme ihtiyaçların giderilmesi bakımından aile üyeleri ile çeşitli rekreatif etkinliklerin yapılması, stres, endişe, depresyon ve sosyal medya bağımlılığ gibi olumsuz etkenler ile mücadele etme konusunda faydalı olabileceği düşünülmektedir "COVID-19 Pandemisinin Aile Yaşantısına Yansımaları” adlı raporda, bireylerin çoğunluğunun, COVID19 pandemi sürecinde evde boş zamanlarını geçirme biçimlerinden memnun kalmadıklarını belirten ifadelere yer verildiği görülmektedir (Göl-Güven vd., 2020: 4). Bu bağlamda Çocuk Hizmetleri Genel Müdürlüğünün "Koronavirüs Sürecinde Ebeveynler ve Çocuk Bakımından Sorumlu Kişiler” için yayınlamış olduğu rehber, ailelere birtakım öneriler sıralamaktadır (www.ailevecalisma.gov.tr). Fiziksel ve zihinsel olarak aktif olmaya özen gösterme kapsamındaki öneriler şu şekilde ifade edilmiştir: "Beraber el sanatları etkinliği yapın, yerel yemek tarifleri ile yemekler pişirin, masal ve hikâyeler okuyun ve anlatın, bir tiyatro köşesi oluşturun ve kuklalar yaparak gösteri sunun, türküler söyleyip, müzik aletleri çalın veya bilmece, mani ve şiirler oluşturun, ailece oyun için özel zaman ayırın, düzenli olarak iletişim kurun, medya kullanımını sınırlayın, ekran kullanım sürenizi düzenleyin”.

Pandemi dönemi boyunca, çeşitli gazete ve dergilerde evde bireysel ve ailecek yapılabilecek bazı etkinlik önerilerinin sunulması, bu konuda toplumsal bir arayışın olduğunun iyi bir kanıtı durumundadır. Diğer taraftan bu konudaki birtakım çözüm önerilerinin de bireyleri geleneklere yönlendirerek SOKÜM ulusal unsurlarına değinmesi ise oldukça dikkat çekicidir. 


\section{GAZETE HABERI}

\begin{abstract}
Kırklareli" nin Babaeski ilçesinde yaşayan ve koronavirüs tedbirleri kapsamında ' 65 yaş' sının nedeniyle evinde kalan Fevzi Yilmaz (67), kuklalar üretip. Hacivat-Karagöz ile vatandașlara 'evde kal' çağnsında bulunuyor.

Koronavirüs tedbirleri kapsamında 65 yaş kısıtlaması nedeniyle günlerdir evinde bulunan Yilmaz, bu süre içinde kendisini sanata verip, yeni kuklalar üretti. Koronavirüs nedeniyle evinde kaldığını söyleyen Yilmaz, "Şimdi evimde yeni kaluplarla birçok kukla karakterleri yaptım, yine gölge oyunlarında Türk-Osmanlı tiyatro tarihinin en popüler iki karakteri olan Hacivat ve Karagöz'ün yeni tasvirlerini yaptım. Hatta amacım tabi bu koronavirüs salgınından kurtulduktan sonra bu yaptığım yeni karakterlerin belgeselini çektikten sonra bunlan Kırklareli Müzesi Müdürlüğü'ne hediye

etmek olacak" dedi.
\end{abstract}

\section{'65 yaş' kısıtlamasında, Hacivat-Karagöz ile 'evde kalın' mesajı veriyor}

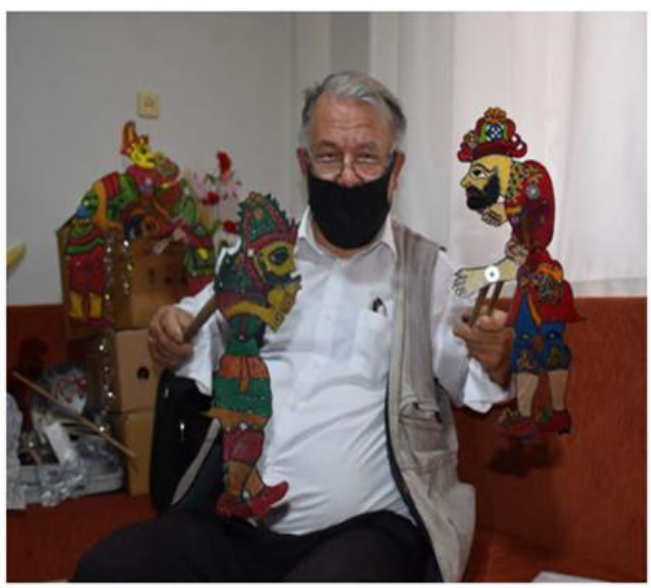

Kaynak: hürriyet (2020).

Resim 1. Vatandaşlara evde kal çağrısı

Haber sitelerinde yer verilen konu ile ilgili başlıklar incelendiğinde, SOKÜM ulusal unsurlarının, içinde bulunduğumuz süreçte bireylere boş zamanı değerlendirmede etkinlik çeşitliliği bakımından potansiyel oluşturabileceği söylenebilir.

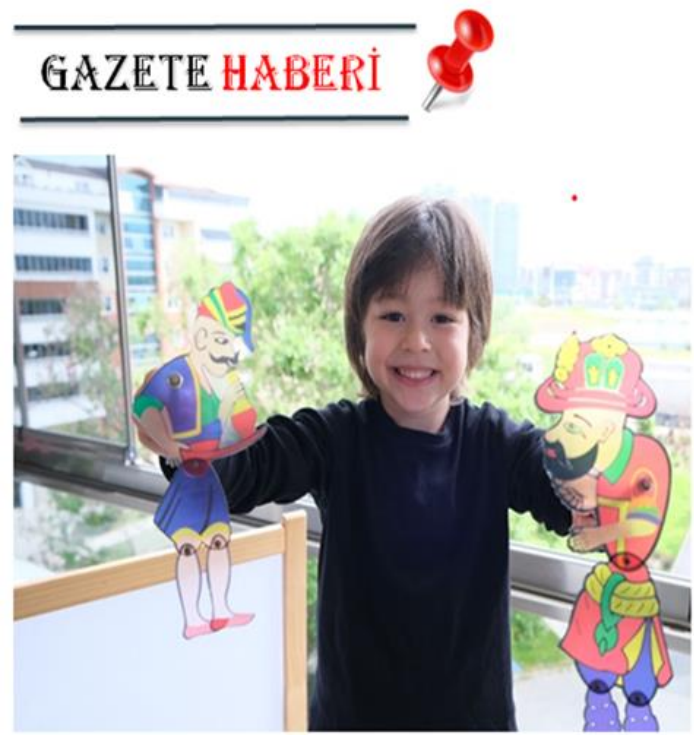

Resim 2. Pandemi sürecinde geleneksel seyirlik oyunu

\section{Balkonda Karagöz-Hacivat Gösterisi}

Bursa' da, 29 Ekim Mahallesinde yaşayan 5 yaşındaki Hakan Sarp Sepetçi sokağa çıkma yasağında evinin balkonunda Karagōz-Hacivat oynatarak arkadaşlarını eğlendirdi. Koronavirüs pandemisi sebebiyle evde kalıp dışarıya çıkamayan 65 yaş üstü vatandaşların belirli süre dışarıya çıkmaları tartışıırken haftalardır evde kalan 20 yaş altı özellikle de kūçük çocukların durumları ebeveynlerini dūşündürmeye başladı. Küçük yaştaki çocuklarını internet ve oyun bağımlıı̆ından uzak tutmak isteyen ebeveynler değişik metotlara bașvurmaya başladı. Nilüfer ilçesinde bir ailede 5 yaşındaki çocukları ve sitedeki diğer tüm çocuklar için evlerinin balkonuna hayali perdesi kurup Karagōz-Hacivat oynattı.

Kaynak: sabah (2020). 


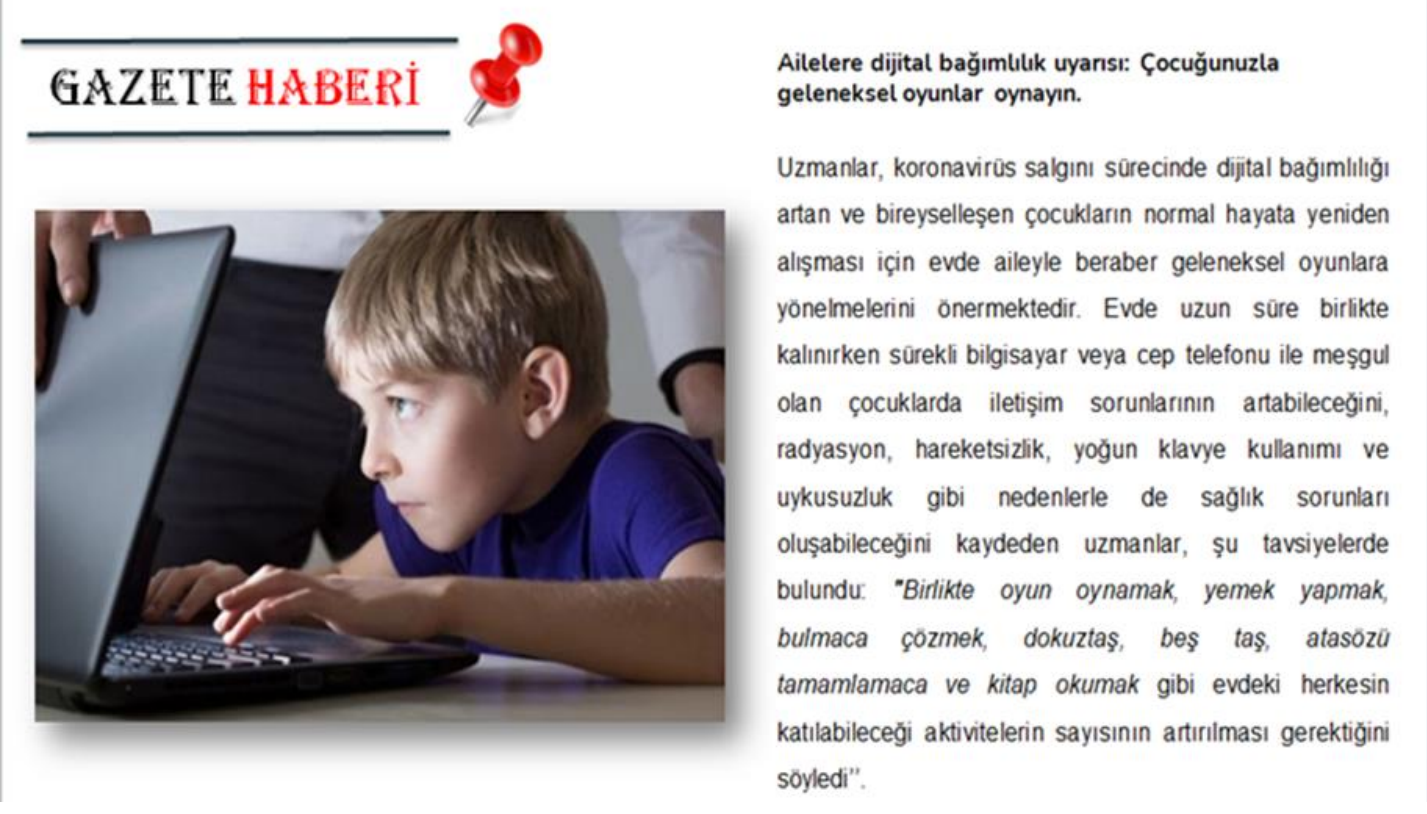

Kaynak: ensonhaber (2020).

Resim 3. Evde yapılacak etkinlik önerisi

Pandemi döneminde evde geçirilen zamanın artması ile aile üyelerinden herhangi birinde oluşabilecek stres, kaygı, endişe ve panik gibi durumlarını en aza indirebilmek adına boş zamanın etkin ve verimli bir biçimde değerlendirilmesinin önemli olduğu görüşü, artık anonim haline gelmiş genel bir kabul görünmektedir. Bu bağlamda eşler anne-baba ve çocukların boş zamanlarını daha verimli ve eğlenceli geçirme arayışlarına yönelik olarak, ev ortamında gerçekleştirilebilecek SOKÜM ulusal unsurları arasından hem bireysel hem de beraberce yapılmaya yatkın olan etkinliklerin seçilmesi, ortak bir etkinlik yaparak kuşaklar arası iletişim sorununu çözmede, yaşlıdan gence doğru geleneksel bilgi aktarımını sağlamada ve genç kuşakların söz konusu miras unsurlarına sahip çıkma konusunda bilinç düzeylerini arttırarak kültür mirasının sürdürülebilirliğini sağlamada etkili olabileceğini söylemek mümkün görünmektedir.

Rekreatif etkinliklerde önemli bir yere sahip olan kültürel etkinlikler, bireyler arasında birlik, beraberlik ve dayanışma gibi durumlara katkı sağlamaktadır (Yavuz ve Altınay Özdemir, 2015: 156). Özellikle evde yapılan kültürel etkinliklerin merkezinde çoğu zaman kültürün somut olmayan unsurları bulunmakta, bu unsurların bir kısmı ise miras niteliğinde olmaktadır. "Miras" kelimesi bir nesilden diğer nesile aktarılan herhangi bir şey olarak ifade edilmektedir (Çevik ve Saçılık, 2016: 332). Kültürel miras ise Fransızca' da "patrimoine” anlamına gelen 
ve "anne ve babadan kalan miras" (Vecco, 2010: 321) biçimde tanımlanmaktadır. Böylece kültürel miras bünyesinde hem somut hem de somut olmayan unsurları da içermektedir (Belber ve Sözbilen, 2019: 899). SOKÜM kavramı, UNESCO tarafından 2003 yılında Paris'teki 32. Genel Konferansı'nda ortaya konan "Somut Olmayan Kültürel Mirasın Korunması Sözleşmesi” ile birlikte dünya gündeminde sağlam bir yere oturmuş ve o tarihten bu yana SOKÜM komsundaki ulusal ve uluslararası düzeyde farkındalık ve çabalar önemli biçimde gelişme göstermiştir. UNESCO'ya göre SOKÜM, "toplulukların, grupların ve kimi durumlarda bireylerin kültürel miraslarının bir parçası olarak tanımladıkları uygulamalar, temsiller, anlatımlar, bilgiler, beceriler ve bunlara ilişkin araçlar, gereçler ve kültürel mekânlar" olarak ele alınmıştır (UNESCO, 2021a). SOKÜM'ün aktarılmasında önemli rol oynayan dil unsuru ile beraber sözlü gelenek ve anlatımlar şu şekildedir (UNESCO,2003: 2);

- Gösteriler,

- Toplumsal uygulamalar, ritüeller, şenlikler,

- Doğa ve evrenle ilgili uygulamalar,

- El sanatları geleneği

Türkiye, UNESCO “Somut Olmayan Kültürel Mirasın Korunması Sözleşmesi”ne taraf olması ile birlikte SOKÜM ulusal envanterini oluşturmaya başlamıştır. Envanter her geçen gün güncellenmekte, en son 18.11.2020 yılı itibarıyla güncellenen söz konusu envanterde halihazırda 35 grupta toplanan unsur sayısı toplam 294'e ulaşmıştır (UNESCO, 2021b). Söz konusu ulusal envanter, ev ortamında ve ister bireysel isterse ailecek yapılabilecek çok sayıda etkinliklere kaynaklık edebilir durumdadır. Ev içi rekreasyonel etkinliklere kaynaklık edecek unsurlar, hepsi geleneksel karakterdeki yiyecek yapımından, zekâ sporlarına, oyunlardan danslara, halk müziği türkü söylemeden anlatı geleneğine, iletişim yöntemlerinden inançlara bağlı uygulamalara, çocuk oyun ve oyuncaklarından müzik aleti yapmaya, oya nakış işlemeden giyim kuşam yapımcılığına, dokuma sanatından çeşitli el sanatlarına ve klasik Türk süsleme sanatına kadar hemen her grupla ilgili görünmektedir. Yine de bazı aile içi rekreasyonel etkinlikler için ihtiyaç duyulan fiziksel alan büyüklüğü, kimisi yoğun malzeme kullanımının doğurabileceği sorunlar, atölye gerekliliği vb. gibi farklı etkilerle bir sınırlama getirmek makul görünmektedir. Buna göre ev içinde tüm aile bireylerinin beraberce yapabileceği rekreasyonel etkinlikler için tavsiye edilebilecek başlıca SOKÜM ulusal unsurları aşağıda Tablo 1'de görülmektedir. 
Tablo 1. Aile içi rekreatif etkinliklere konu olabilecek bazı soküm ulusal unsurlarına örnekler

\begin{tabular}{|c|c|c|}
\hline $\begin{array}{l}\text { Envanter } \\
\text { Numarasi }\end{array}$ & Grup & Unsurun Adı \\
\hline 1.002 .02 & Geleneksel El Sanatı Ustalığ1 & 1.Ahşap Oymacılı̆̆ \\
\hline 1.002.10 & Geleneksel El Sanatı Ustalığ1 & 2.Tahta Kaşık Geleneği \\
\hline 1.002.16 & Geleneksel El Sanatı Ustalığ1 & 3.Foklorik Bebek Yapımı \\
\hline 1.002 .18 & Geleneksel El Sanatı Ustalığ1 & 4.Çömlekçilik \\
\hline 1.002.24 & Geleneksel El Sanatı Ustalığ1 & 5.Lületaşı İşleme Sanatı \\
\hline 1.004 .02 & Dokuma Sanatı Geleneği & 6.Halı Dokuma Geleneği \\
\hline 1.008 .01 & $\begin{array}{l}\text { Geleneksel Çocuk Oyunları } \\
\text { Oyuncakları }\end{array}$ & $\begin{array}{l}\text { 7.Geleneksel } \text { Oyuncaklar ve } \quad \text { Oyuncak } \\
\text { Yapımcılığ1 }\end{array}$ \\
\hline 1.008 .02 & $\begin{array}{l}\text { Geleneksel Çocuk Oyunları } \\
\text { Oyuncakları }\end{array}$ & $\begin{array}{l}\text { 8.Çocuk Oyunları Oynama Gelenekleri } \\
\text { (Topaç, saklambaç, birdirbir, körebe vs.) }\end{array}$ \\
\hline 1.025 .03 & $\begin{array}{l}\text { Anlatı Geleneği ve Geleneksel } \\
\text { Söz Sanatları }\end{array}$ & 9.Dede Korkut Kültürü \\
\hline 1.025 .06 & $\begin{array}{l}\text { Anlatı Geleneği ve Geleneksel } \\
\text { Söz Sanatları }\end{array}$ & 10.Nasreddin Hoca F1kra Anlatı Geleneği \\
\hline 1.025 .07 & $\begin{array}{l}\text { Anlatı Geleneği ve Geleneksel } \\
\text { Söz Sanatları }\end{array}$ & 11.F1kra Anlatma Geleneği \\
\hline 1.025.08 & $\begin{array}{l}\text { Anlatı Geleneği ve Geleneksel } \\
\text { Söz Sanatlanı }\end{array}$ & 12.Masal Anlatma Geleneği \\
\hline 1.025 .09 & $\begin{array}{l}\text { Anlatı Geleneği ve Geleneksel } \\
\text { Söz Sanatları }\end{array}$ & 13.Mâni Söyleme Geleneği \\
\hline 1.025 .10 & $\begin{array}{l}\text { Anlatı Geleneği ve Geleneksel } \\
\text { Söz Sanatları }\end{array}$ & 14.Bilmece Sorma Geleneği \\
\hline 1.028 .02 & $\begin{array}{l}\text { Halk Müziği ve Türkü Söyleme } \\
\text { Geleneği }\end{array}$ & 15.Ninni Söyleme Geleneği \\
\hline 1.030 .02 & $\begin{array}{l}\text { Geleneksel Seyirlik Sanatlar ve } \\
\text { Oyunlar }\end{array}$ & 16.Karagöz \\
\hline 1.030 .03 & $\begin{array}{l}\text { Geleneksel Seyirlik Sanatlar ve } \\
\text { Oyunlar }\end{array}$ & 17.Kukla \\
\hline 1.031.08 & Geleneksel Sporlar & $\begin{array}{l}\text { 18.Geleneksel Zekâ ve Strateji Oyunu: } \\
\text { Mangala/Göçürme }\end{array}$ \\
\hline 1.027 .03 & Geleneksel Sporlar & 19.Âşık Oyunu \\
\hline 1.035.01 & $\begin{array}{l}\text { Türk Mutfak Kültürü/ Geleneksel } \\
\text { Yiyecek İçecek Yapımı }\end{array}$ & 20.Türk Kahvesi Kültürü ve Geleneği \\
\hline 1.035 .04 & $\begin{array}{l}\text { Türk Mutfak Kültürü/ Geleneksel } \\
\text { Yiyecek İçecek Yapımı }\end{array}$ & 21.İnce Ekmek Geleneği: Yufka ve Lavaş \\
\hline 1.035 .34 & $\begin{array}{l}\text { Türk Mutfak Kültürü/ Geleneksel } \\
\text { Yiyecek İçecek Yapımı }\end{array}$ & 22.Çay Kültürü \\
\hline 1.035 .43 & $\begin{array}{l}\text { Türk Mutfak Kültürü/ Geleneksel } \\
\text { Yiyecek İçecek Yapımı }\end{array}$ & 23.Arabaşı Geleneği \\
\hline
\end{tabular}

Kaynak: (TC. Kültür ve Turizm Bakanlığg, aregem, 2020). 
Kültür mirasının unsurlarını barındıran geleneksel rekreatif oyunlar ile ev içerisindeki boş zamanların değerlendirilmesi, ebeveynlere eskiyi anımsatarak çocuklar için de kendi kültürlerindeki oyunları oynama fırsatı sunabilecektir (Uslu vd., 2020: 16). Dolayısıyla SOKÜM unsurları dikkate alınarak gerçekleştirilen aile içi rekreatif etkinliklerin, ebeveynler tarafından bu mirasın çocuklara aktarımı noktasında köprü oluşturacağı açıkça görülmektedir.

\section{YÖNTEM}

$\mathrm{Bu}$ çalışmanın amacı COVID-19 pandemi sürecinde SOKÜM ulusal unsurlarının aile içi rekreatif etkinliklerde ne derece rol alabileceği sorusuna cevap verebilmek ve pandemi sürecinin SOKÜM unsurlarının sürdürülebilirliğine katkı yapabileceği çıkarımına yönelik kanıtlar bulabilmektir. Çalışmada yöntem olarak, ilgili konuda pandemi sürecinde yayınlanan makalelerin incelenmesiyle oluşan sistematik derleme benimsenmiştir. Aynı zamanda çalışmada ikincil verilerin analizinden de yararlanılmıştır. Sistematik derleme, belirli bir alandaki araştırmaları gözden geçirme yöntemi olarak ifade edilmektedir. Literatürün belirli kriterler dahilinde sistemli bir şekilde incelenmesidir (Hanley ve Cutts, 2013; Ercan, 2020). Konu ile ilgili literatür eğilimlerini belirleme ve haritalandırmada etkili bir yöntem olduğu ifade edilmektedir (Teoh vd., 2021; 178). Sistematik derleme 3 ana adımı içermektedir; (1) kriterlerin belirlenmesi, (2) potansiyel makalelerin belirlenmesi ve seçilmesi (3) seçilen makalelerin sınıflandırılmasıdır (Larrea vd., 2021; 2). Dolayısıyla belirli bir ilgi alanıyla ilgili mevcut çalışmaların sonuçlarını tanımlamak, sentezlemek ve değerlendirmek için yapılan bir yöntemdir (Shafiee vd., 2019; 290).

COVID-19 pandemi sürecinin başladığ 11 Mart 2020 tarihi itibariyle konu ile ilgili olarak benzer içeriğe sahip makalelere ulaşmak için ulusal ve uluslararası veri tabanlarında belirlenen anahtar kelimelerle taramalar gerçekleştirilmiştir. Bu bağlamda makale tarama işlemi 30.05.2021-10.06.2021 tarihleri arasında uluslararası veri tabanları (Web of Science, Taylor Francis, Elsevier) ve ulusal veri tabanlarında (Google Akademik ve Dergi Park) gerçekleştirilmiştir. $\mathrm{Bu}$ kapsamda çalışma konusuna uygun benzerlikte olan 10 makale çalışması tespit edilmiş ve analize tabi tutulmuştur. Araştırmada uygulanan sistematik derleme yöntemi için belirlenen tarama kriterleri aşağıda Tablo 2'de gösterilmektedir. 
Tablo 2. Tarama kriterleri

\begin{tabular}{|l|l|}
\hline Kriterler & Uygulama \\
\hline Kriter 1: Taranan Veri tabanları & $\begin{array}{l}\text { Web of Science, Taylor Francis, Elsevier, } \\
\text { Google Akademik, Dergi Park }\end{array}$ \\
\hline Kriter 2: Aranan Anahtar Kelimeler (EN/TR) & $\begin{array}{l}\text { "In-family recreation activities and intangible } \\
\text { cultural heritage (ICH)" } \\
\text { "COVID-19 and indoor activities" } \\
\text { "Aile içi rekreasyonel aktivelerde (SOKÜM)" } \\
\text { "COVID-19 ve kapalı alan aktiveleri" }\end{array}$ \\
\hline Kriter 3: Yayın Türü & Araştırma ve Derleme Makaleleri \\
\hline Kriter 4: Yayın Dili & İngilizce ve Türkçe \\
\hline Yayınların tarih aralı̆ğ & Mart 2020-Mayıs 2021 \\
\hline
\end{tabular}

Kaynak: (Ercan, 2020; 5236)

\section{BULGULAR}

Belirlenen tarama kriterlerine göre ve çalışmanın amacına uygun olarak COVID-19 pandemi sürecinde aile içi rekreasyonel etkinliklerde SOKÜM konusunda benzer içeriklere sahip ulusal ve uluslararası veri tabanlarında yayınlanmış makalelerin 2020 ve 2021 yıllarına göre dağılımı Tablo 3 'te gösterilmektedir.

Tablo 3. Çalışmaların künyesi

\begin{tabular}{|c|l|l|l|}
\hline Yıl & Yazar(lar) & Çalışmanın Adı & $\begin{array}{l}\text { Araştırma yöntemi ve } \\
\text { veri kaynağı }\end{array}$ \\
\hline 2020 & $\begin{array}{l}\text { Gümüş̧ül ve } \\
\text { Aydoğan }\end{array}$ & $\begin{array}{l}\text { Yeni Tip Koronavirüs-COVID-19 } \\
\text { Kaynaklı Evde Geçirilen Boş Zamanların } \\
\text { Ev İçi Rekreatif Oyunlar ile } \\
\text { Değerlendirilmesi }\end{array}$ & $\begin{array}{l}\text { Nitel, doküman } \\
\text { incelemesi ve tarama } \\
\text { modeli }\end{array}$ \\
\hline 2020 & $\begin{array}{l}\text { Uslu, } \\
\text { Karavelioğlu ve } \\
\text { Gümüşgül }\end{array}$ & $\begin{array}{l}\text { Geleneksel Rekreatif Oyunlar: Yeni } \\
\text { Koronavirüs (COVID-19) Salgını } \\
\text { Sürecinde Boş Zaman Değerlendirme } \\
\text { Önerileri }\end{array}$ & $\begin{array}{l}\text { Nitel, doküman } \\
\text { incelemesi ve literatür } \\
\text { taraması }\end{array}$ \\
\hline 2020 & $\begin{array}{l}\text { Güzel, Yıldız, } \\
\text { Esentaş ve } \\
\text { Zerengök }\end{array}$ & $\begin{array}{l}\text { "Know-How" to Spend Time in Home } \\
\text { Isolation during COVID-19; Restrictions } \\
\text { and Recreational Activities }\end{array}$ & $\begin{array}{l}\text { 479 katıllımcı ile karma } \\
\text { araştırma yöntemi }\end{array}$ \\
\hline 2020 & $\begin{array}{l}\text { Jae Kim, Hyung } \\
\text { Cho ve Ji Park } \\
\text { in Preventive Health Behaviors and Their } \\
\text { Experience of Constraints on Performing } \\
\text { Leisure Activities During the COVID-19 } \\
\text { Pandemic }\end{array}$ & $\begin{array}{l}\text { Nicel, 544 katıllımc1 ile } \\
\text { anket }\end{array}$ \\
\hline 2020 & $\begin{array}{l}\text { Yücedağ ve } \\
\text { Çetin }\end{array}$ & $\begin{array}{l}\text { Identifying Leisure Perceptions and } \\
\text { Activities of EFL Teachers in Home } \\
\text { Isolation during the COVID-19 Pandemic }\end{array}$ & $\begin{array}{l}\text { Nicel, 939 katıllımc1 ile } \\
\text { anket }\end{array}$ \\
\hline
\end{tabular}




\begin{tabular}{|c|c|c|c|}
\hline 2020 & Tüzel & $\begin{array}{l}\text { COVID-19 Salgını Sürecinde E1 Sanatları } \\
\text { Geleneği Deneyimleri }\end{array}$ & $\begin{array}{l}\text { Nitel, doküman } \\
\text { incelemesi ve literatür } \\
\text { taramas1 }\end{array}$ \\
\hline 2021 & $\begin{array}{l}\text { Chiarello, } \\
\text { Palisano, Avery } \\
\text { ve Hanna }\end{array}$ & $\begin{array}{l}\text { Longitudinal Trajectories and Reference } \\
\text { Percentiles for Participation in Family and } \\
\text { Recreational Activities of Children with } \\
\text { Cerebral Palsy }\end{array}$ & $\begin{array}{l}18 \text { ay- } 12 \text { yaş aralığında } \\
708 \text { çocuk ve ebeveynleri } \\
\text { ile karma araştırma } \\
\text { yöntemi }\end{array}$ \\
\hline 2021 & $\begin{array}{l}\text { Kalleson, } \\
\text { Jahnsen ve } \\
\text { Ostensjo }\end{array}$ & $\begin{array}{l}\text { Exploring participation in family and } \\
\text { recreational activities among children } \\
\text { with cerebral palsy during early } \\
\text { childhood: how does it relate to motor } \\
\text { function and parental empowerment? }\end{array}$ & Nicel, 56 aile ile anket \\
\hline 2021 & Yıldız ve Bektaş & $\begin{array}{l}\text { COVID-19 Salgınının Çocukların Boş } \\
\text { Zaman Etkinliklerinde Yarattığı } \\
\text { Değişimin Ebeveyn Görüşleriyle } \\
\text { Değerlendirilmesi }\end{array}$ & $\begin{array}{l}\text { Nitel, } 32 \text { katılımc1 ile } \\
\text { mülakat }\end{array}$ \\
\hline 2021 & $\begin{array}{l}\text { Nurimanov ve } \\
\text { Kishkenbayeva }\end{array}$ & $\begin{array}{l}\text { An Investigation of Aitys and The Poems } \\
\text { on Pandemic in Kazakhstan During The } \\
\text { Pandemic (COVID-19) }\end{array}$ & $\begin{array}{l}\text { Nitel, doküman } \\
\text { incelemesi }\end{array}$ \\
\hline
\end{tabular}

Gümüşgül ve Aydoğan'In (2020), bireylere yeni tip Koronavirüs kaynaklı evde kalma süreçlerinde uygulayabilecekleri ev içi rekreatif oyunlar konusunda tavsiyelerde bulunma amacıyla yapmış oldukları çalışmada, rekreatif oyunların koronavirüsten kaynaklı stres ve kaygıların yaşanmasına engel olabileceği, aile bireylerine evde geçirilen süreçte daha aktif hareket etme imkânı oluşturabileceği vurgulanmaktadır.

Uslu, Karavelioğlu ve Gümüşgül'ün (2020), pandemi sebebiyle sokağa çıkma kısıtlamalarının birey hareketliliğini sınırlaması, psikolojik ve fizyolojik sağlık sorunlarının önüne geçebilmek adına ortaya koydukları çalışmada, ev ortamında özellikle yaşlı ve genç nüfusun hareketsiz kalma durumlarını en aza indirebilmek amacıyla egzersiz, zamanın daha keyifli geçmesini sağlamak içinse geleneksel rekreatif oyunların fayda sağlayacağ düşünülmektedir.

Güzel, Yıldız, Esentaş ve Zerengök'ün (2020), COVID-19 pandemi yayılımını önlemek amacıyla alınan tedbirlerle bir süre evde vakit geçirmek zorunda kalan bireylerin fiziksel, psikolojik ve duygusal durumlarını ve ne tür rekreasyonel aktiviteleri tercih ettiklerini belirlemek için yaptıkları çalışmada, katılımcıların pandemide ekonomik, sosyal, psikolojik ve fizyolojik açıdan olumsuz yönde etkilendikleri ancak sosyal izolasyon sürecinde aile bireyleri ile birlikte yapılan rekreatif aktivitelerin paylaşımı artması, yeni şeyler keşfetme, verimli ve keyifli zaman geçirme gibi olumlu etkilerinin olduğu sonucuna varılmıştır. 
Jae Kim, Hyung Cho ve Ji Park'ın (2020), COVID-19 pandemi sürecinde boş zaman spor aktiviteleri yapan bireylerin boş zaman kısıtlarını belirlemek amacıyla ortaya koydukları çalışmalarında, kadınların erkeklere kıyasla COVID-19 önleyici davranışları daha yüksek oranda benimsedikleri, pandemi sürecinde sağlıklarını korumak amacıyla açık alandan ziyade ev içi boş zaman spor aktivitelerinin tercih edildiği ifade edilmektedir.

Yücedă̆ ve Çetin'in (2020), Koronavirüs salgını sırasında Türkiye'deki İngilizce öğretmenlerinin boş zaman etkinlikleri hakkındaki düşünce ve algılarını ortaya koymak amacıyla yaptıkları bu çalışmada ise çoğunun evde kalma sürecinin boş zaman aktivitelerini artırdığı ifadesi ile karşılaşılmıştır. Aynı zamanda evde vakit geçirme sürecinin hem aile ilişkilerini olumlu yönde geliştirdiği hem de hobiler için iyi bir imkân oluşturduğu sonucuna ulaşı1mıştır.

Tüzel'in (2020), çalışmasında SOKÜM Korunması Sözleşmesi'nin beş alanından biri olan el sanatları geleneğinin pandeminin olumlu ve olumsuz etkileri karşısındaki durumu ele alınmaktadır. Salgın ile beraber benimsenen yeni yaşam biçiminde, el sanatları geleneği aktarım yolunun da dijital platformlar aracılığı ile gerçekleştirildiği ifade edilmektedir. Çalışmada, toplumsal bir iyileşme aracı olarak el sanatları etkinliklerinin aktarım ve korunmasının pandemi gibi kriz dönemlerinde de devam ettiği sonucu ile karşılaşılmıştır. Modern çağa uygun olarak, gelecek kuşaklara kültürel miras aktarımı noktasında, el sanatları ustalarının temel bilgi teknolojileri konusunda etkin olması gerekliliği bir diğer önemli sonuç olarak ifade edilmektedir.

Chiarello, Palisano, Avery ve Hanna (2021), bu çalışmada serebral palsi (SP) hastalığı olan çocukların evde aile ile birlikte rekreasyon etkinliklerine katılım sıklıklarına odaklanmaktadır. Rekreasyon etkinliklerine katılımın serebral palsili (SP) çocukların motor becerilerine fayda sağladığı böylelikle çocuğun aile tarafından desteklenmesinin etkinlik katılım oranını olumlu yönde etkileyebileceği sonucuna ulaşılmıştır.

Kalleson, Jahnsen ve Ostensjo'nun (2021), Erken çocukluk döneminde serebral palsili (SP) çocukların aile ile beraber rekreasyonel etkinliklere katılımını, kaba ve ince motor işlevlerinin gelişimine yönelik bulguları ortaya koyma amacıyla yaptıkları çalışmalarında, çocukların hem aileyle hem de kendi başlarına yaptıkları rekreatif etkinlikler, bilgi ve beceri kazanmaları açısından önemli görülmektedir. Bu nedenle çocukların yeni aktivite ortamlarına uyum sağlamaları veya yeni rollerle sosyalleşmelerinde ebeveynleri tarafından teşvik edilmenin 
katkısı olduğu ifade edilmektedir. Çocuklar arasındaki kaba ve ince motor işlev seviyelerine dayalı benzerlikler ve farklılıkların, rekreasyon etkinliklerine katılım ile bağlantılı olduğu sonucuna ulaşılmıştır. Aile içinde rekreatif etkinliklere çocuk katılımının ebeveyn teşviki ile güçlendirilmesi durumu, çalışmada küçük bir çocuğun hayatındaki önemli bir nokta olarak özetlenmektedir.

Yıldız ve Bektaş'ın (2021), COVID-19 pandemisinin çocukların boş zaman etkinliklerinde meydana getirdiği değişimi belirleme amacıyla yaptıkları çalışmalarında, 32 katılımcı ile yapılan görüşme sonucunda pandemi dönemi öncesine göre çocukların hareket oranları ve sosyalleşme seviyelerinin azaldığı bu durumun da kişilik ve karakter gelişimlerini olumsuz etkileyebileceği ifade edilmiştir. Pandemi ile birlikte hasta olma endişesinin çocukları ileri düzeyde etkilediği, böylelikle çocukların sosyal hayata uyum sağlayabilme noktasında aile desteğinin önemli olduğu sonucuna ulaşılmıştır.

Nurimanov ve Kishkenbayeva 'nın (2021), çalışmasında küresel salgın sürecinde (SOKÜM) ulusal unsurlarının arasında yer alan âşı atışması geleneğinin farklı bir boyutta yeni bir biçim kazandığı belirtilmektedir. COVID-19 salgınından korunma amacıyla evde vakit geçiren Kazak halkının salgın sürecinde dâhi boş zamanlarında âşık atışması geleneğini korumaya çalıştığı görülmektedir. Âşık atışması geleneğinin salgın nedeni ile online platformlar üzerinden devam ettirilmesi, bu geleneğin gelecek kuşaklara sürdürülebilir bir aktarım biçimi sunduğu sonucu ortaya koyulmaktadır.

\section{SONUÇ VE ÖNERÍLER}

COVID-19 pandemi süreci, farklı kuşaklara ait bireylerin belki de ilke kez aynı ortamda ve bu kadar uzun sürede bir arada olmalarını gerektirmiştir. Bu durum aileleri, boş zamanlarını beraberce eğlenceli ve verimli geçirebilecekleri rekreasyonel etkinlik arayışına itmiş, bu noktada aile bireylerinin çoğu zaman uygun çözümleri bulamadığı gözlenmiştir. Bu çalışma COVID-19 pandemi sürecinde bir anlamda evlerine hapsolmuş olan bireylerin, boş zamanlarını verimli ve eğlenceli geçirmelerinde SOKÜM ulusal unsurlarının bir fırsat sunmasına odaklanmaktadır. $\mathrm{Bu}$ konudaki literatürün COVID-19 pandemi sürecinin başlangıcı düşünülürse, oldukça yeni ve bir o kadar da sınırlı olduğu anlaşılabilmektedir. Bu önemli sınırlılıklara rağmen ilgili konudaki mevcut literatür, bu çalışma ile derlenmiştir.

Yapılan sistematik derleme ile elde edilen sonuçlara göre, SOKÜM ulusal unsurlarının aile içi rekreatif etkinliklerde üstlenebileceği role ilişkin 2020 ve 2021 yıllarında yayınlanan ulusal ve 
uluslararası çalışmaların oldukça sınırlı sayıda olduğu görülmektedir. COVID-19 pandemi sürecinde, başta çocuklar olmak üzere aile bireylerinin internet ve sosyal medya bağımlılıkları önemli bir araştırma problemi haline gelerek birçok araştırmaya konu olmuştur (Duygulu ve Hepkon, 2021; Baltacı vd., 2021; Liu vd., 2021; Pennington, 2021; Adıbelli ve Sümen 2020). $\mathrm{Bu}$ araştırmanın odağına daha yaklaşır biçimde pandemi sürecinde aile içi rekreatif etkinlikler konusunu içeren çalışmaların ise, hareketsiz geçen zaman problemine çözüm üretme amaçlı olarak özellikle sağlık ve spor ana teması ile ele alındığ 1 ve değerlendirildiği tespit edilmiştir (Martin vd., 2021; Kyriazis vd., 2020; Tükel, 2021; Kaplan ve Demir, 2021; Fang vd., 2021). Ancak pandemi süreci içinde, aile içi rekreatif etkinlikler kaynağı olarak SOKÜM konusunu ele alan sadece (Nurimanov ve Kishkenbayeva, 2021) yaptığı bir makaleye rastlanmıştır. Bu anlamda çalışma, COVID-19 gibi aile ortamında zorunlu zaman geçirmeyi verimli ve eğlenceli hale getirebilecek SOKÜM unsurlarından yararlanma fikrini ortaya koyarak, sonraki çalışmalara kapı açan öncü bir çalışma olarak görülebilir. Bu bağlamda yapılacak çalışmaların ilgili konudaki literatürün gelişime önemli ölçüde katkılar sağlayabileceği düşünülmektedir.

$\mathrm{Bu}$ çalışma sonucunda, pandemi sürecinin getirileri konusunda anne-baba ve çocukların hem olumlu hem de olumsuz yönden deneyimler elde ettikleri söylenebilir. Böylelikle, pandemi ile birlikte bireylerin günlük rutinlerinin yeni bir boyut kazanması ve hareket alanlarının kısıtlanması sebebi ile bu sürecin evde geçirilmesi, ailelerin daha çok evde yapılan rekreatif etkinlikleri tercih etmelerinde önemli bir neden olarak görülebilir. Bu bağlamda, pandemi sürecinin hemen tüm dünya halkları için, kendi SOKÜM ulusal unsurlarının tanınmasında ve bir rekreasyon etkinliği olarak ele alınmasında önemli bir firsat sunduğunu ifade etmek mümkündür. Türkiye bağlamında ifade edilecek olursa, oldukça zengin SOKÜM ulusal envanterinin boş zamanların verimli ve eğlenceli geçirilmesinde çok seçenekli firsatlar sunduğunu söylemek mümkündür. Üstelik buna yönelik çabaların, SOKÜM ulusal unsurlarının sürdürülebilirliği için de önemli bir firsat yaratacağı düşünülebilir. Çalışma bir bütün olarak göz önüne alındığında, pandemi sürecinde ve devam eden süreçte SOKÜM ulusal unsurlarının aile içi rekreasyonel etkinliklerde önemli bir kaynak haline gelebilmesi için kamu kurumları, sivil toplum, akademi ve özel sektörün birtakım sorumluluklar yüklenmesi gerektiği ortaya çıkmaktadır. Bu paydaşların üstleneceği sorumluluklar bağlamında aşağıda çeşitli öneriler sunulmuştur. 
- SOKÜM ulusal unsurları ile ilgili konu ve uygulamaların, okul öncesi, ilköğretim, ortaöğretim ve diğer eğitim kademelerindeki öğretim programlarında gerektiği ölçüde yer alarak bu konuda toplumsal farkındalığın arttırılması,

- SOKÜM ulusal unsurlarını ailenin psikolojik sağlığına destek olur nitelikte, önemli bir aile içi rekreasyon etkinlik kaynağı olabilecek şekilde özendirilmesi,

- Bu konuda mobil uygulamalar, kamu spotu desteği ve rehber kitapçıklar hazırlanması,

- Oyuncak sektörünün SOKÜM ulusal unsurlarının kaynaklık ettiği ve uygulamaları kolaylaştıran yeni ürünler tasarlaması,

- Akademinin SOKÜM ulusal unsurlarının rekreatif etkinlik olarak aile yaşantısındaki yeri ve önemi konusunda aynı zamanda çözüm önerileri sunan araştırmalar yapması,

- Türkiye'nin bu hamlelerle, UNESCO tarafından da dile getirildiği üzere tüm dünyanın sorunu olan SOKÜM sürdürülebilirliğinde liderlik yapması.

Sonuç olarak, SOKÜM ulusal unsurlarının aile içi rekreatif etkinliklerde rol almasının, aile içi iletişimin artmasında, kültürel değerlerin kuşaktan kuşağa aktarımında, kuşaklar arası çatışmayı azaltmada, geçirilen boş zamanın verimli ve aynı zamanda eğlenceli hale gelmesinde, mobil cihazlar ve internet bağımlılığını azaltmada ve tüm bunların bileşkesi olarak kaybolma tehdidiyle karşı karşıya olan SOKÜM ulusal unsurlarının yeniden üretimini sağlayarak sürdürülebilmesinde önemli faydaları olabileceği düşünülmektedir. Ayrıca COVID-19 pandemi döneminin ne kadar süre daha devam edeceğinin net bir cevabı olmadığ için, evde geçirilen süre boyunca dünya toplumlarının kendi kültürel değerleri konusunda daha da bilinçli hale gelmesi noktasında fursat oluşturduğu ifade edilebilir. Yer verilen öneriler dâhilinde, gelecekte yapılacak olan çalışmalarda, SOKÜM ulusal unsurlarının rekreatif etkinlikler bağlamında daha detaylı değerlendirilmesi bakımından nitel veya nicel yöntemler kullanılarak farklı boyutlarda ele alınması da gerekli görülmektedir. 


\section{KAYNAKÇA}

Adıbelli, D., Sümen, A., (2020). The Effect of the Coronavirus (COVID-19) Pandemic on HealthRelated Quality of Life in Children. Children and Youth Services Review, 119, 1-7.

Aregem, (2020). T.C. Kültür ve Turizm Bakanlığı. Somut Olmayan Kültürel Miras Ulusal Envanteri.https://aregem.ktb.gov.tr/TR-159257/somut-olmayan-kulturel-mirasulusalenvanteri .html Erişim Tarihi: 5.12.2020.

Baltac1, Ö., Akbulut, Ö. F., Yılmaz, E. (2021). Problemli İnternet Kullanımında Güncel Bir Risk Faktörü: Covid-19 Pandemisi. Atıf Cite Humanistic Perspective, 3 (1), 97-121.

Başaran, M., Aksoy, A. B. (2020). Anne-Babalarin Korona-Virüs (COVID-19) Salgını Sürecinde Aile Yaşantılarına İlişskin Görüşleri. Uuslararası Sosyal Araştırmalar Dergisi, 31(71), 1307-9581.

Belber, B. G., Sözbilen, G. (2019). Turizm Öğrencilerinin Boş Zaman Etkinlikleri İçerisinde Somut Olmayan Kültürel Miras (Soküm) Unsurlarının Yeri. Üçüncü Sektör Sosyal Ekonomi Dergisi, 54(2), 897-916.

Chiarello, L. A., Palisano, R. J., Avery, L., Hanna, S., (2021). Longitudinal Trajectories and Reference Percentiles for Participation in Family and Recreational Activities of Children with Cerebral Palsy. Physical \& Occupational Therapy in Pediatrics, 41(1), 18-37.

Çevik, S., Yıldırım Saçılık, M. (2016). Somut Olmayan Kültürel Miras Unsurlarının Yenilikçi Turizm Ürünlerine Dönüştürülmesi: Bir Örnek Olay İncelemesi. International Journal of Social Science, 47, 331-341.

Çocuk Hizmetleri Genel Müdürlüğü. (2020). Koronavirüs Sürecinde Ebeveynler ve Çocuk Bakımından Sorumlu Kişiler İçin Rehber. https://www.ailevecalisma.gov.tr/media/47720/koronavi-ru-s-su-reci-nde-c-ocuklarin desteklenmesi.pdf. (Erişim Tarihi: 27.01.2021).

Dalkılıç, G., Mil, B. (2017). Rekreasyon-Animasyon Hizmetlerinin Sınıflandırılması ve Otel İşletmelerindeki Öneminin Değerlendirilmesi. Beykoz Akademi Dergisi, 5(2), 40-72.

Dikmen, M. (2021). COVID-19 Pandemisinde Üniversite Öğrencilerinin Depresyon Düzeyleri ile Sosyal Medya Bağımlılıkları Arasındaki İlişki: Bir Yapısal Eşitlik Modeli. Bağımlılık Dergisi, 22(1), 20-30.

Duygulu, S., Hepkon, Z. (2021). Teknolojik Bağımlılık mı Teknolojik Yeterlilik mi? Covid-19 Pandemisine Bağlı Olarak Artan Ekran Süresi Bağlamında Aile ve Öğretmenlerin Gençlerin Teknoloji Kullanımına Dönük Yaklaşımlarının İncelenmesi. Communication and Technology Congress - CTC (April 12th-14th, 2021 - Turkey, Istanbul). 
Ensonhaber, (2020 Ağustos, 26). [Ailelere dijital bağımlılık uyarısı: Çocuğunuzla geleneksel oyunlar oynayın]. https://www.ensonhaber.com/egitim-haberleri/ailelere-dijital-bagimlilik-uyarisicocugunuzla-geleneksel-oyunlar-oynayin.

Ercan, F. (2020). Akıllı Turizmde Büyük Veri Kullanımı: Sistematik Bir Derleme. Uluslararas1 Toplum Araştırmaları Dergisi, 16(32), 5232-5249.

Fang, Y., Zhu, L., Jiang, Y., Wu, B. (2021). The Immediate and Subsequent Effects of Public Health Interventions for COVID-19 on the Leisure and Recreation Industry. Tourism Management, $87,1-8$.

Göl-Güven, M., Şeker, V., Erbil, F., Özgünlü, M., Alvan, G., Uzunkök, B. (2020). COVID-19 Pandemisinin Aile Yaşantısına Yansımaları Rapor-2. Technical Report. 1-30.

Gümüşü̈l, O., Aydoğan, R. (2020). Yeni Tip Koronavirüs-Covid 19 Kaynaklı Evde Geçirilen Boş Zamanların Ev İçi Rekreatif Oyunlar ile Değerlendirilmesi. Spor Eğitim Dergisi, 4(1), 107 114.

Gürçayır Teke, S. (2013). Geleneksel Tarzlar, Modern Modeller: Resmî, Resmî Olmayan Eğitim Ve Somut Olmayan Kültürel Miras. Milli Folklor Dergisi, 25(100), 31-39.

Gürel, D., Çetin, T., (2019). Somut Olmayan Kültürel Miras Tutum Ölçeği: Geçerlik ve Güvenirlik Çalışması. Bartın Üniversitesi Eğitim Araştırmaları Dergisi, 8(1), 82-102.

Güzel, P., Yıldız, K., Esentaş, M., Zerengök, D. (2020). "Know-How" to Spend Time in Home Isolation during COVID-19; Restrictions and Recreational Activities. International Journal of Psychology and Educational Studies, 7(2), 122-131.

Hacıoğlu, N., Gökdeniz, A., Dinç, Y. (2017). Boş Zaman ve Rekreasyon Yönetimi. (4.Baskı). Detay Yayıncılık, Ankara.

Hanley, T., Cutts, L. (2013). What is A Systematic Review. Counselling Psychology Review, 28(4), 36.

Hürriyet, (2020 Nisan, 28). ['65 yaş' kısıtlamasında, Hacivat-Karagöz ile 'evde kalın' mesajı veriyor]. https://www.hurriyet.com.tr/gundem/65-yas-kisitlamasinda-hacivat-karagoz-ile-evde-kalinmesaji-veriyor-41504872.

Jae Kim, Y., Hyung Cho, J., Ji Park, Y. (2020). Leisure Sports Participants' Engagement in Preventive Health Behaviors and Their Experience of Constraints on Performing Leisure Activities during the COVID-19 Pandemic. Frontiers in Psychology, 11(589708), 1-9.

Kalleson, R., Jahnsen, R., Ostensjo, S. (2021). Exploring Participation in Family and Recreational Activities among Children with Cerebral Palsy during Early Childhood: How Does it Relate to Motor Function and Parental Empowerment? Disability and Rehabilitation, 21(1), 1-11. 
Kaplan, K., Demir, D. (2021). Covid-19 Pandemi Sürecinde Kısıtlı Serbest Zamanda Fiziksel Aktiviteye Katılan Yaşlı Bireyler Üzerine Nitel Bir Araştırma. Journal of National Sport Sciences, 5(2), 122-137.

Kılbaş, Ş. (2010). Rekreasyon Boş Zamanı Değerlendirme. (4.Baskı).Gazi Kitapevi, Ankara.

Kurtar, C. (2012). Kentsel Kültürel Miras Yönetimi Ve Rekreasyonla İlişkisi: Ankara Hamamönü Örneği. Yüksek Lisans Tezi. Ankara Üniversitesi Sosyal Bilimler Enstitüsü. Ankara.

Kyriazis, A., Mews, G., Belpaire, E., Aerts, J., Malik, S. A. (2020). Physical Distancing, Children and Urban Health: The COVID-19 Crisis' Impact on Children and How This Could Affect Future Urban Planning and Design Policies. Cities \& Health, 1-6.

Landry, C. E., Bergstrom, J., Salazar, J., Turner, D. (2020). How Has The COVID-19 Pandemic Affected Outdoor Recreation in The U.S.? A Revealed Preference Approach. Available at SSRN: https://ssrn.com/abstract=3690373 or http://dx.doi.org/10.2139/ssrn.3690373.

Larrea, G. L., Altın, M., Köseoğlu, M. A., Okumuş, F. (2021). An İntegrative Systematic Review of İnnovation Research in Hospitality and Tourism. Tourism Management Perspectives, 37, 1-14.

Liu, H., Liu, W., Yoganathan, V., Osburg, V. S., (2021). COVID-19 Information Overload and Generation Z's Social Media Discontinuance Intention during the Pandemic Lockdown. Technological Forecasting and Social Change, 166, 1-12.

Martin, A. M., Champ, F., Franklin, Z. (2021). COVID-19: Assessing the Impact of Lockdown on Recreational Athletes. Psychology of Sport and Exercise, 56, 1-11.

MEB,(2020).http://www.meb.gov.tr/uzaktan-egitim-30-nisana-kadar-devamedecek/haber/20585/tr.

Erişim Tarihi:30.11.2020.

Nurimanov, B., Kishkenbayeva, Z. (2021). An Investigation of Aitys and The Poems on Pandemic in Kazakhstan during the Pandemic (COVID-19) Milli Folklor 129, 98-110.

Pennington, N. (2021). Communication Outside of the Home Through Social Media during COVID19. Computers in Human Behavior Reports, 4, 1-8.

Saglik, (2020). T.C. Sağlık Bakanlığı COVID-19 Bilgilendirme Sayfası. https://covid19.saglik.gov.tr/ Erişim Tarihi: 3.12.2020.

Sabah, (2020 Mayıs, 3). [Balkonda Karagöz-Hacivat gösterisi].https://www.sabah.com.tr/bursa/2020/05/03/balkonda-karagoz-hacivat-gosterisi.

Shafiee, S., Ghatari, A. R., Hasanzadeh, A., Jahanyan, S. (2019). Developing a Model for Sustainable Smart Tourism Destinations: A Systematic Review. Tourism Management Perspectives, 31, 287-300. 
Shamshiripour, A., Rahimi, E., Shabanpour, R. ve Mohammadian, A, K. (2020). How is COVID-19 reshaping activity-travel behavior? Evidence from a comprehensive survey in Chicago. Transportation Research Interdisciplinary Perspectives 7, 1-16.

Szabo, T. G., Richling, S., Embry, D. D., Biglan, A., Wilson, K. G. (2020). From Helpless To Hero: Promoting Values-Based Behavior and Positive Family Interaction in the Midst Of COVID19. Behavior Analysis in Practice, 13, 568-576.

Taştan, N. (2020). Rekreasyon Paradigması. Taşkın, C. (Ed.). Gazi Kitapevi, Ankara.

Tekin, A., Tekin, G., Çalışır, M. (2017). Rekreasyon Bilimi 2. Karaküçük, S., Kaya, S., Akgül, B. M. (Ed.). Ankara: Gazi Kitapevi.

Teoh, M. W., Wang, Y., Kwek, A. (2021). Conceptualising Co-Created Transformative Tourism Experiences: A Systematic Narrative Review. Journal of Hospitality and Tourism Management, 47, 176- 189.

TÜIK, (2020). Türkiye İstatistik Kurumu Hanehalkı Bilişim Teknolojileri Kullanım Araştırması.https://data.tuik.gov.tr/Bulten/Index?p=Hanehalki-Bilisim-Teknolojileri-(BT)Kullanim-Arastirmasi-2020-33679. (Erişim Tarihi:28.01.2021).

Tükel, Y. (2021). Covid-19 Sürecinde Rekreatif Faaliyetlere Katılan Bireylerin Psikolojik Sağlamlık Düzeylerinin İncelenmesi. Başkent Üniversitesi Sağlık Bilimleri Fakültesi Dergisi, 6(1), 91104.

Tüzel, B. (2020). COVID-19 Salgını Sürecinde El Sanatları Geleneği Deneyimleri. Millî Folklor 127, $87-100$

UNESCO, (2003). Somut Olmayan Kültürel Mirasın Korunması Sözleşmesi. https://ich. unesco.org/doc/src/00009-TR-PDF.pdf. Erişim Tarihi: 30.11.2020.

UNESCO, (2021a). https://www.unesco.org.tr/Pages/181/177/. Erişim Tarihi: 20.06.2021.

UNESCO, (2021b). İnsanlığın Somut Olmayan Kültürel Mirası Temsilî Listesi https://www.unesco.org.tr/Pages/126/123/UNESCO\%C4\%B0nsan1\%C4\%B1\%C4\%9F\%C4\% B1n-Somut-Olmayan-K\%C3\%BClt\%C3\%BCrel-Miras\%C4\%B1-Temsil\%C3\%AE-Listesi. Erişim Tarihi: 20.06.2021.

Uslu, S., Karavelioğlu, M. B., Gümüşgül, O., (2020). Geleneksel Rekreatif Oyunlar: Yeni Koronavirüs (COVID-19) Salgını Sürecinde Boş Zaman Değerlendirme Önerileri. Spor ve Rekreasyon Araştırmaları Dergisi, 2 (1), 14-25.

Vecco, M. (2010). A Definition of Cultural Heritage: From the Tangible to the İntangible. Journal of Cultural Heritage, 11, 321-324. 
Yavuz, E., Altınay Özdemir, M. (2015). Rekreasyon Etkinliklerine Katılımda Somut Olmayan Kültürel Mirasın Rolü. III. Rekreasyon Araştırmaları Kongresi, Anadolu Üniversitesi, Eskişehir.

Yıldız, S., Bektaş, F. (2021). COVID-19 Salgınının Çocukların Boş Zaman Etkinliklerinde Yarattığı Değişimin Ebeveyn Görüşleriyle Değerlendirilmesi. Gazi Beden Eğitimi ve Spor Bilimleri Dergisi, 26(1), 99-122.

Yücedağ, C., Çetin, M. (2020). Identifying Leisure Perceptions and Activities of EFL Teachers in Home Isolation during the COVID-19 Pandemic. Journal of Engineering and Sciences, 6(2), $62-72$.

WHO, (2020). Modes of transmission of virus causing COVID-19: implications for IPC precaution recommendations.https://www.who.int/news-room/commentaries/detail/modes-of transmission-of-virus-causing-COVID-19-implications-for-ipc-precaution-recommendations. Erişim Tarihi: 3.12.2020

1. Çıkar Çatışması Beyanı: Makalenin yazarları arasında çıkar çatışması bulunmamaktadır.

2. Etik Kurul İzin Belgesi: Makalede etik kurulu izni ve/veya yasal/özel izin alınmasını gerektiren bir durum yoktur. Çalışmayla ilgili veriler ikincil veri olarak elde edilmiştir.

3. Araştırmacıların Katkı Oranı Beyanı: Araştırmacıların katkı oranı eşittir.

4. Destek ve Teşekkür Bilgisi: Bu çalışma sırasında kıymetli bilgi, birikim ve tecrübeleri ile bana yol gösterici ve destek olan değerli hocam sayın Prof. Dr. Bilgehan GÜLCAN'a, sonsuz teşekkür ve saygılarımı sunarım. 


\section{The Role That Intangible Cultural Heritage National Elements in In-Family Recreation Activities Might Take During Covid-19 Pandemic \\ Bilgehan GÜLCAN}

Ankara Hacı Bayram Veli University, Faculty of Tourism, Ankara/Turkey

Damla ERDEM

Kırklareli University, Faculty of Tourism, Kırklareli/Turkey

\section{Extensive Summary}

\section{Introduction}

During the COVID-19 period we live in, all individuals are forced to spend more time in their homes. It has been commonly encountered that this circumstance led individuals within families to pursue ways to spend more enjoyable and effective time together or alone, and in case of not being able to achieve this, individuals have been faced with intense stress. In this pursuit, it was seen that some elements found in the countries' national inventory of Intangible Cultural Heritage (ICH) might offer required potential that could be the answer to the pursuit in question and pandemic process can make a contribution to the sustainability of ICH elements within this dimension. In this context, the study aims to address the question of to what extent ICH national elements can play a role in domestic recreational activities during the pandemic process and uncover evidence for the statement that the pandemic process can contribute to the sustainability of ICH elements.

\section{Literature Review}

As a result of the limitation of contact between individuals, the interruption of education in schools, the execution of many commercial and duty activities from home, and the cessation of activities in many areas where leisure time is spent, the duration of individuals staying at home has increased dramatically. (Gumusgul and Aydogan, 2020: 108). All these developments have pushed individuals to seek fun and productive ways to spend their spare time, both independently and collectively within the family. As a result of this search due to the increase in the time spent at home, it is thought that the national elements of Intangible Cultural Heritage (ICH) create an attractive environment by offering individuals and families of different individuals the opportunity to spend productive and enjoyable time. Thus, the research aims to analyze the opportunity to have a productive and enjoyable time created by the national elements of Intangible Cultural Heritage (ICH), where both parents and children can do activities together during the pandemic process. In addition to the challenges of the process, it is believed that such an opportunity can contribute not only to individuals having a 


\section{Ankara Hacı Bayram Veli Üniversitesi Turizm Fakültesi Dergisi \\ Erdem ve Gülcan, 2021, Cilt: 24, Sayl: 2, 192-215}

productive and fun time, but also to the sustainability of these elements by reproducing national elements of Intangible Cultural Heritage (ICH), many of which have been forgotten and/or neglected. In this way, the difficulty of spending free time together in the family can turn into a fun opportunity, and individuals of all ages who are more inclined to spend time on social media, especially depending on mobile devices, will have the opportunity to get to know the national elements of Intangible Cultural Heritage (ICH) more closely.

\section{Methodology}

The aim of this study is to answer the question to what extent Intangible Cultural Heritage (ICH) national elements can play a role in domestic recreational activities during the COVID-19 pandemic process and to find evidence for the inference that the pandemic process can contribute to the sustainability of Intangible Cultural Heritage (ICH) elements. As a method in the study, a systematic review formed by examining the articles published during the pandemic process was adopted. At the same time, the analysis of secondary data was also used in the study. Systematic review is expressed as a method of reviewing research in a particular field. It is a systematic examination of the literature within certain criteria (Hanley \& Cutts, 2013; Ercan, 2020). It is stated that it is an effective method in identifying and mapping the literature trends on the subject (Teoh et al., 2021; 178). The systematic compilation includes 3 main steps; (1) determination of criteria, (2) identification and selection of potential articles, and (3) classification of selected articles (Larrea et al., 2021; 2). Therefore, it is a method for identifying, synthesizing and evaluating the results of existing studies on a particular area of interest (Shafiee et al., 2019; 290). As of March 11, 2020, when the COVID-19 pandemic process began, searches were carried out with the keywords determined in national and international databases to reach articles with similar content on the subject. In this context, the article search was carried out in international databases (Web of Science, Taylor Francis, Elsevier) and national databases (Google Scholar and Journal Park) between 30.05.2021 and 10.06.2021. In this context, 10 articles that are similar to the subject of the study were identified and analyzed.

\section{Conclusions}

The COVID-19 pandemic process required individuals from different generations to be together in the same environment for such a long time, perhaps for the first time. This situation has led families to seek recreational activities where they can spend their free time together fun and productive. At this point, it has been observed that family members often cannot find suitable solutions. This study focuses on the national elements of Intangible Cultural Heritage (ICH) to provide an opportunity for individuals who are, in a sense, confined to their homes during the COVID-19 pandemic process, to spend their free time productively and enjoyable. Considering the beginning of the COVID-19 


\section{Ankara Hacı Bayram Veli Üniversitesi Turizm Fakültesi Dergisi \\ Erdem ve Gülcan, 2021, Cilt: 24, Sayl: 2, 192-215}

pandemic process, it can be understood that the literature on this subject is quite new and so limited. Despite these important limitations, the current literature on the subject has been compiled with this study.

According to the results obtained with the systematic review, it is seen that the national and international studies published in 2020 and 2021 on the role that the national elements of Intangible Cultural Heritage ( $\mathrm{ICH}$ ) can play in family recreational activities are quite limited. During the COVID-19 pandemic process, internet and social media addictions of family members, especially children, have become an important research problem and have been the subject of many studies (Duygulu and Hepkon, 2021; Baltac1 et al., 2021; Liu et al., 2021; Pennington, 2021; Adibelli and Sümen 2020). Closer to the focus of this research, it has been determined that studies involving family recreational activities during the pandemic process are handled and evaluated with the main theme of health and sports in order to find solutions to the problem of sedentary time (Martin et al., 2021; Kyriazis et al., 2020).; Tükel, 2021; Kaplan and Demir, 2021; Fang et al., 2021). However, during the pandemic process, only one article (Nurimanov and Kishkenbayeva, 2021) was found that deals with the issue of Intangible Cultural Heritage (ICH) as a source of family recreational activities. In this sense, the study can be seen as a pioneering study that opens the door to further studies by introducing the idea of benefiting from Intangible Cultural Heritage (ICH) elements that can make spending time in the family environment productive and enjoyable, such as COVID-19. It is thought that the studies to be carried out in this context can contribute significantly to the development of the related literature.

As a result, the participation of SOKÜM national elements in family recreational activities, increasing family communication, transferring cultural values from generation to generation, reducing intergenerational conflict, making leisure time productive and enjoyable at the same time, reducing mobile devices and internet addiction, and the combination of all these. It is thought that it may have important benefits in sustaining the national elements of Intangible Cultural Heritage (ICH), which are threatened with disappearance, by ensuring their reproduction. 